\title{
STRATEGICZNE WYZWANIA DLA POLSKIEJ POLITYKI ZAGRANICZNEJ W KONTEKŚCIE PREZYDENCJI W RADZIE UNII EUROPEJSKIEJ W 2011 ROKU
}

1 lipca 2011 roku Polska przyjęła swoją pierwszą w historii prezydencję w Radzie Unii Europejskiej (dalej: RUE). Od tego momentu, przez sześć miesięcy Rzeczpospolita Polska przewodniczy pracom RUE współuczestnicząc i współzarządzając Unią Europejską ${ }^{1}$. Do głównych zadań w ramach sprawowania przewodnictwa należy: przewodniczenie pracom Rady Unii Europejskiej i jej organów pomocniczych (komitety i grupy robocze) oraz przewodniczenie spotkaniom Rady Europejskiej ${ }^{2}$ (organizowanie

1 W celu skoordynowania mechanizmu reprezentowania wszystkich państw członkowskich Unii Europejskiej w stosunkach zewnętrznych i dążenia do jednolitego reprezentowania Unii na arenie międzynarodowej, stosuje się formułę Trójki. Odnosi się ona do Wspólnej Polityki Zagranicznej i Bezpieczeństwa i jest instrumentem koordynacji merytorycznej i chronologicznej. W jej skład wchodzą: minister spraw zagranicznych bieżącej Prezydencji, jego odpowiednik z kraju mającego sprawować następną prezydencję, przewodniczący Komisji Europejskiej oraz Sekretarz Generalny/Wysoki Przedstawiciel UE ds. Wspólnej Polityki Zagranicznej i Bezpieczeństwa. Szerzej: J. Ruszkowski, Prezydencja jako mechanizm koordynujacy wewnatrz Unii Europejskiej. Znaczenie otwartej metody koordynacji, w: 2011 Polska Prezydencja w Unii Europejskiej, red. R. Riedel, P. Klimontowski, Opole 2010, s. 48. Innym mechanizmem, w którym uczestniczą trzy podmioty jest „Trio Prezydencji”. Okres sześciu miesięcy jest zbyt krótki, aby państwo sprawujące prezydencję mogło skutecznie zrealizować założone cele swojego przewodnictwa. W związku z tym wykrystalizowała się koncepcja prezydencji grupowej, w której trzy państwa sprawujące po sobie przewodnictwo koordynują między sobą główne cele, jakie zamierzają zrealizować w czasie 18 miesięcy. Skuteczność tej koncepcji zapewnia też założenie, że każde Trio składa się z państwa dużego i państw mniejszych, a także i to, że w każdej trójce są państwa tzw. starej i nowej UE. Polska, będzie pierwszym i największym państwem Trio, w skład którego wchodzą Królestwo Danii i Republika Cypryjska. Szerzej: Polska Prezydencja w Unii Europejskiej, http://www.prezydencjaue.gov.pl/co-to-jest-trio-prezydencji (12.01.2011).

2 Rada Unii Europejskiej, jest głównym - obok Parlamentu Europejskiego - organem prawodawczym Unii Europejskiej. Jest to organ międzyrządowy. Rada działa w różnych formacjach, w ramach których państwa członkowskie reprezentowane są przez delegowanych ministrów, kierujących w swych krajach resortami odpowiedzialnymi za problemy rozpatrywane na forum Rady i odbywa się to w dziesięciu konfiguracjach: Rada do spraw Ogólnych; Rada do spraw Zagranicznych; Rada do spraw Gospodarczych i Finansowych; Rada do spraw Współpracy w dziedzinie Wymiaru Sprawiedliwości i Spraw Wewnętrznych; Rada do spraw Zatrudnienia, Polityki Społecznej, Zdrowia i Polityki dotyczącej Konsumentów; Rada do spraw Transportu, Telekomunikacji i Energii; Rada do spraw Rolnictwa i Rybołówstwa; Rada do spraw Ochrony Środowiska; Rada do spraw Konkurencji i Rada do spraw Edukacji, Młodzieży i Kultury. Z wyjątkiem Rady do Spraw Zagranicznych, której z urzędu przewodniczy Wysoki Przedstawiciel UE do Spraw Zagranicznych i Polityki Bezpieczeństwa, poszczególnym składom Rady przewodniczy prezydencja. Rada Europejska jest najwyższą instytucją 
w wymiarze merytorycznym i logistycznym unijnych spotkań z bardzo szerokim spektrum podejmowanych zagadnień; reprezentowanie Rady wobec innych instytucji UE - głównie Komisji Europejskiej i Parlamentu Europejskiego); reprezentowanie Unii Europejskiej w stosunkach z państwami trzecimi i organizacjami międzynarodowymi, przy współpracy z Wysokim Przedstawicielem ds. Polityki Zagranicznej i Bezpieczeństwa oraz Komisarzem ds. Stosunków Zewnętrznych ${ }^{3}$.

Janusz Ruszkowski, analizując teoretyczne aspekty prezydencji RUE, w oparciu o teorię neoinstytucjonalizmu oraz instytucjonalizmu normatywnego przy wykorzystaniu logiki stosowności, wysunął wniosek o jej generalnie rządowo-neutralnym charakterze, tzn. niezależnym wobec interesów rządu sprawującego rotacyjnie prezydencję. Pozycja ta wzmocniona jest o funkcję międzyrządowej RUE tworzącą ponadnarodowe prawo wspólnotowe wtórne. W tym kontekście paradoksem jest, że RUE uznawana za instytucję reprezentującą interesy rządów narodowych generuje legislację, która stanowi trzon prawa wspólnotowego o charakterze ponadnarodowym. Stosowane w ramach RUE oraz prezydencji instrumenty koordynacyjne (m.in.: rady sektorowe, Trojka, Open Method of Coordination, Committee of Permanent Representatives - COREPER, passarelle, Gymnich Formula) stanowią również funkcje pomostu pomiędzy poziomem międzyrządowym a ponadnarodowym. Ponadto, jeżeli dane zagadnienie lub polityka sektorowa ma być poddana koordynacji, automatycznie jest wprowadzana do międzyrządowego systemu instytucjonalnego nadzorowanego przez RUE, Radę Europejską oraz prezydencję, a następnie zostaje poddana oddziaływaniu mechanizmu koordynacyjnego w systemie międzyrządowym. $\mathrm{Z}$ kolei cechy pomostowe tego mechanizmu przyczyniają się - poza wspomnianą koordynacją - do uwspólnotowienia danej kwestii (wyniesienia na poziom ponadnarodowy). Działanie RUE oraz prezydencji i natura interakcji między różnymi urzędnikami tych instytucji wykazuje zachowania ponadnarodowe oraz chęci do kompromisu pomiędzy partykularnymi stanowiskami narodowymi w celu promowania wspólnego interesu UE jako całości. W związu z tym mechanizm koordynacyjny prezydencji może służyć także do uwspólnotowienia zagadnień dotąd rozstrzyganych na poziomie międzyrządowym w Unii Europejskiej. Efekty jego działania można określić jedynie na tle innych instrumentów i wydaje się być jedynie jednym $\mathrm{z}$ wielu trybów $\mathrm{w}$ systemie ${ }^{4}$.

Pomimo to, analiza szans, jakie państwu członkowskiemu stwarza objęcie przewodnictwa w Unii Europejskiej, powala wyciagnąć wnioski, że podmiot taki może jednak wykorzystać związane z prezydencją możliwości oddziaływania na proces decyzyjny, w celu realizacji również własnych partykularnych interesów. Wynika to z uprawnień

polityczną Unii Europejskiej, która decyduje o kierunkach jej rozwoju i aktualnej strategii działania. Co prawda, nie należy do pięciu głównych instytucji UE, ale jest wobec nich strukturą nadrzędną. Jej rodowód wywodzi się z nieformalnych spotkań głów państw i szefów rządów państw członkowskich Wspólnot Europejskich odbywanych nieregularnie od 1961 roku, których inicjatorem był Charles de Gaulle. Zob: M. Molendowska, Prezydencja Rady Europejskiej-szansq dla Polski?, w: 2011 Polska Prezydencja w Unii Europejskiej..., op. cit., s. 81.

3 A. Kosowska, Czy jest o co walczyć? Prezydencja Rady Unii Europejskiej i jej znaczenie dla państw członkowskich, w: 2011 Polska Prezydencja w Unii Europejskiej..., op. cit., s. 140-143.

4 J. Ruszkowski, Prezydencja jako mechanizm koordynujacy wewnatrz Unii Europejskiej..., op. cit., s. 55-57. 
formalnych i nieformalnych, roli przypisywanej prezydencji oraz przewagi informacyjnej, co przejawia się uzyskaniem wpływu na kształtowanie agendy oraz przebieg negocjacji wewnątrz RUE oraz z innymi podmiotami. Ma to szczególnie znaczenie dla państw małych i średnich, których zasoby strukturalne oraz liczbę głosów ważonych w Radzie znacznie trudniej wykorzystać do budowania własnej pozycji w Unii Europejskiej $^{5}$. Koordynacyjna, administracyjna, mediacyjna i reprezentacyjna funkcja prezydencji stanowią dla państw członkowskich okazję, by w większym niż zwykle stopniu wpływać na europejską politykę. Ponadto rotacyjna prezydencja daje im okazję do poprawy bądź promowania wizerunku czy też budowania własnej marki (tzw. brand building).

Każda z prezydencji poprzedzona jest żmudnymi przygotowaniami, opracowaniem programu przewodnictwa oraz przygotowaniem administracyjnym. Opracowuje się także na jej użytek strategię komunikacyjna, która ma na celu umocnienie dobrego wizerunku państwa w świecie. W przypadku polskiej prezydencji miał to być wizerunek Polski, jako kraju nowoczesnego i zdolnego sprostać nowym wyzwaniom. Okazją do kształtowania pozytywnego postrzegania kraju stały się różnego rodzaju wydarzenia kulturalne oraz promocja turystycznych walorów Polski. Dużą wagę przywiązano do stworzenia profesjonalnego serwisu internetowego, jako wizytówki państwa przewodniczącego Radzie UE. Uznano, iż sprawnie i dynamicznie poprowadzone przewodnictwo to szansa, aby zaprezentować się jako świetny organizator czy sprawny mediator i tym samym przykuć uwagę opinii publicznej. Jest to tym ważniejsze, że po przyjęciu Traktatu lizbońskiego prezydencję okrojono z funkcji reprezentacyjnej. Na zmniejszenie roli prezydencji wpływ ma umocnienie roli Wysokiego Przedstawiciela Unii ds. Polityki Zagranicznej i Bezpieczeństwa, który przejął, przysługujące dotychczas przywódcy państwa pełniącego prezydencję, prawo reprezentowania UE na arenie międzynarodowej.

Istotne jest też pozbawienie prezydencji możliwości działań, związanych z udziałem w międzynarodowych konferencjach i negocjacjach oraz występowaniem w imieniu UE jako całości, w szczególności wobec najważniejszych państw świata.

$Z$ jednej strony oznacza to zwolnienie z obowiązku, ale z drugiej pozbawienie przywileju organizacji szczytów Unii Europejskiej z państwami trzecimi m.in.: Rosją, Stanami Zjednoczonymi i ChRL. Ponadto wyłączono Radę ds. Zewnętrznych z systemu rotacyjnego przewodnictwa. W związku z tym jej pracom nie będzie już przewodniczył minister państwa sprawującego prezydencję, co znacząco uszczupla merytoryczny zakres spraw należących do kompetencji prezydencji ${ }^{6}$. Na mocy Traktatu lizbońskiego powołano ponadto stałego przewodniczącego Rady Europejskiej (szczytów gromadzących szefów państw i rządów UE), jako pierwszy został nim Belg Herman Van Rompuy. Ta instytucja również odebrała część kompetencji państwu sprawującemu przewodnictwo, które nadal zwołuje szczyty (decydowanie o terminie i o tym, czy potrzebny jest np. dodatkowy szczyt), ale nie uczestniczy w tworzenia przesłania szefów państw i rządów, będącego efektem prac Rady Europejskiej ${ }^{7}$.

5 M. Kleinowski, Wplyw sprawowania Prezydencji Rady na kształtowanie się siły państw członkowskich, w: 2011 Polska Prezydencja w Unii Europejskiej..., op. cit., s. 79.

6 A. Kosowska, Czy jest o co walczyć..., op. cit., s. 140-143.

7 D. Pszczółkowska, Prezydencja po lizbońsku w sosie narodowym, „Gazeta Wyborcza”, 24.03.2011. 
Z drugiej strony wskazuje się na spore możliwości prezydencji w zakresie tworzenia agendy UE (tzw. agenda-shaping). Prezydencja daje państwom ją sprawującym szansę na sterowanie aktywnością prawodawczą Unii Europejskiej również w odniesieniu do narodowych priorytetów, zwłaszcza gdy zyskują one zrozumienie wśród pozostałych partnerów w UE. Ponadto przewodnictwo to umożliwia prezentację własnej wizji integracji europejskiej. Wiąże się też z możliwością uruchamiania wielu środków formalnych i nieformalnych umożliwiających przełamywanie sytuacji kryzysowych podczas negocjacji i otwiera możliwość aktywnego nań oddziaływania. Przewodnictwo ma więc istotne cele w zakresie określania priorytetów Unii Europejskiej i budowania związanych z tym kompromisów i porozumień. Jednak musi być przeprowadzone w sposób efektywny i legitymizowany ${ }^{8}$.

Już w styczniu 2009 roku Rada Ministrów zaakceptowała program przygotowań Polski do przewodnictwa w Radzie Unii Europejskiej. 22 lipca 2010 roku rząd przyjął dokument, z którego wynika, że główne cele polskiej prezydencji będą oscylować wokół m.in.: Wieloletnich Ram Finansowych 2014-2020, stosunków ze Wschodem, rynku wewnętrznego, wzmocnienia wspólnej polityki energetycznej UE, wspólnej polityki bezpieczeństwa i obrony, podpisania traktatu akcesyjnego z Chorwacją, rozpoczęcia debaty o unijnej strategii wobec Rosji czy wzmocnienia Partnerstwa Wschodniego? .

W dobie kryzysu finansów światowych, Unia Europejska szuka metod stymulacji wzrostu gospodarczego. Polska prezydencja postuluje wzmocnienie rynku wewnętrznego Unii Europejskiej, w którym jak się wydaje tkwi potencjał dla wzrostu unijnej gospodarki. Rozwijanie rynku wewnętrznego UE to kontynuowanie działań na rzecz swobodnego przepływu towarów, osób, usług i kapitału. Polskie działania skoncentrowały się m.in. na rozpoczęciu dyskusji nad pogłębianiem liberalizacji usług na rynku wewnętrznym, regulacjach dotyczących sektora finansowego lub znoszeniu barier w handlu. Ponadto, wspólnie z Wysokim Przedstawicielem Unii Europejskiej ds. Polityki Zagranicznej i Bezpieczeństwa, polska prezydencja miała dążyć do podniesienia sprawności UE w sferze zarządzania kryzysowego, pogłębienia współpracy państw członkowskich w dziedzinie obronności oraz zapewnienia partnerstwa z NATO.

Wśród pozostałych priorytetów polskiego przewodnictwa UE wymienia się m.in. pełne wykorzystanie kapitału intelektualnego Europy. Zrównoważony i sprzyjający rozwojowi społecznemu wzrost gospodarczy będzie możliwy przy pełnym wykorzystaniu wszystkich możliwości społeczno-gospodarczych, jakie tkwią w poszczególnych państwach członkowskich. Dzięki temu będzie możliwe zapewnienie dalszej spójności społecznej, gospodarczej i terytorialnej Unii Europejskiej. Polska prezydencja zakładała wypełnienie tej luki poprzez podjęcie tematu kapitału intelektualnego na forum Unii Europejskiej. Dodatkowym ważnym elementem programu stały się inicjatywy o silnym wydźwięku społeczno-ekonomicznym: Europejski Rok Wolontariatu,

8 J. Jaskiernia, Polska jako gospodarz posiedzenia Konferencji Komisji Wyspecjalizowanych w Sprawach Wspólnotowych i Europejskich Parlamentów Unii Europejskiej (COSAC) w ramach Prezydencji w Unii Europejskiej, w: 2011 Polska Prezydencja w Unii Europejskiej..., op. cit., s. $193-197$.

9 Wstępne priorytety polskiej Prezydencji zaakceptowane, http://www.premier.gov.pl/rzad/decyzje_rzadu/id:5071/ (12.02.2011). 
Europejski Kongres Kultury, podjęcie problematyki osób niepełnosprawnych czy Forum Rynku Wewnętrznego ${ }^{10}$. Szczegółowy program polskiego przewodnictwa został przedstawiony do zatwierdzenia przez Radę Ministrów w marcu 2011 roku. Rozpisano w nim zadania dla poszczególnych ministerstw, które przez pół roku prowadzić miały obrady różnych unijnych rad sektorowych (czyli spotkań ministrów) - od rolnictwa, przez edukację i przemysł do konkurencyjności. Trzeba przyznać, iż powstał on w wyjątkowo trudnym momencie, gdy na kryzys w strefie euro nałożyły się rewolty w północnej Afryce, które maja poważne konsekwencje gospodarcze i społeczne dla państw UE. Zatem tworzony przez wiele miesięcy program musiał ulec modyfikacjom, ale generalnie Polska przewodząc RUE zakładała skupienie się na realizacji trzech priorytetów: integracji europejskiej jako źródła wzrostu gospodarczego; bezpieczeństwie europejskim i stabilnym sąsiedztwie. Tempo realizacji tych priorytetów ma zależeć od rozwoju sytuacji na świecie i klimatu politycznego w Unii Europejskiej ${ }^{11}$.

Na okres polskiej prezydencji przypadło rozpoczęcie rozmów o unijnym budżecie na lata 2014-2020. Jednak w tym przypadku dominująca okazuje się rola koordynacyjna przewodnictwa REU, aniżeli możliwość promowania partykularnych interesów. Zwłaszcza, że Polska jest stroną zainteresowaną utrzymaniem wysokiego finansowania polityki spójności, która pozwala państwom tzw. „,nowej” Unii nadrobić cywilizacyjny dystans do państw „starej” UE. Trzeba jednak pamiętać, że negocjacje w sprawie unijnego budżetu, są w polityce wewnętrznej kluczowym czynnikiem stanowiącym o sukcesie polskiego przewodnictwa. Szczególnie, że na czas polskiej prezydencji przypadł etap dogłębnej analizy propozycji Komisji Europejskiej i identyfikacji głównych zagadnień negocjacyjnych. Rozmowy na ten temat rozpoczęły się w połowie 2011 roku i będą trwały do drugiej połowy 2012 roku $^{12}$.

Polska jest jedynym spośród sześciu największych państw UE, zwolenników utrzymania funduszy spójności. Można tego dokonać pozyskując głosy innych bogatych państw z biedniejszymi regionami jak: Hiszpania czy Portugalia. Z kolei, w ramach unijnej polityki rolnej, znacznie łatwiej jest obronić dopłaty mając poparcie większej liczby liczących się przywódców z francuskim prezydentem Nicolasem Sarkozym na czele $^{13}$.

Równie trudnym zadaniem okazało się wypracowanie strategii wzrostu gospodarczego Unii. Jest to niełatwe, zwłaszcza w kontekście kryzysu gospodarczego i poczynienia związanych $\mathrm{z}$ tym koniecznych oszczędności. To, co leżało w zakresie możliwości prezydencji związane jest z wzmocnieniem konkurencyjności, liberalizacją sektora usług oraz rozwojem handlu elektronicznego (m.in. zniesienie barier w międzynarodowych transakcjach online) ${ }^{14}$.

10 Wstęna lista priorytetów polskiego przewodnictwa w Radzie Unii Europejskiej w II połowie 2011 r., dokument przedłożony przez pełnomocnika rządu ds. przygotowania organów administracji rządowej i sprawowania przez Rzeczpospolitą Polską przewodnictwa w Radzie Unii Europejskiej, http://www.premier.gov.pl/rzad/decyzje_rzadu/id:5071 (12.02.2011).

11 J. Pawlicki, Unia po polsku - ostatnia faza przygotowań do prezydencji, „Gazeta Wyborcza”, 15.03.2011.

12 Wstęna lista priorytetów polskiego przewodnictwa w Radzie Unii Europejskiej..., op. cit.

13 J. Pawlicki, Arabska prezydencja Polski, „Gazeta Wyborcza”, 11.03.2011.

14 J. Pawlicki, Unia po polsku..., op. cit. 
Pomimo mniejszej niż przed wejściem w życie Traktatu lizbońskiego możliwości oddziaływania na unijną politykę zagraniczną, Polska podczas swojej prezydencji, przystąpiła do realizacji kilku ambitnych zamierzeń w ramach polityki zewnętrznej Unii Europejskiej. W sprawie unijnych aspiracji Turcji i Islandii trudno spodziewać się przełomu, ale państwa bałkańskie jak: Macedonia, Albania, Czarnogóra, Serbia, Bośnia i Hercegowina, liczyły że w trakcie polskiej prezydencji zintensyfikują negocjacje z Unią Europejską. Pod koniec czerwca 2011 roku Chorwacja zakończyła negocjacje akcesyjne i na polskie przewodnictwo przypadnie uroczystość podpisania jej traktatu akcesyjnego do Unii Europejskiej. Decyzja ta zakończyła sześcioletnie negocjacje, rozpoczęte w 2005 roku i dała możliwość przyjęcia tego państwa do Unii Europejskiej 1 lipca 2013 roku. Traktat akcesyjny z Chorwacją ma zostać podpisany w ciagu pół roku, czyli w czasie polskiego przewodnictwa i następnie musi zostać ratyfikowany, aby Chorwacja stała się 28 członkiem UE. Trzeba pamiętać, że klimat dla rozszerzenia nie był w Unii Europejskiej najlepszy - niezbyt przychylne rozszerzeniu są władze Francji i Holandii. Chociaż pod względem gospodarczym Chorwacja jest równie gotowa do członkostwa, jak były Bułgaria czy Rumunia; wykazuje się najwyższym poziomem rozwoju gospodarczego w regionie, sprawnie funkcjonującą gospodarką rynkową i jest w stanie realizować zasady Jednolitego Rynku Europejskiego; to na przeszkodzie członkostwa stały problemy polityczne w Chorwacji i wysoki stopień korupcji, ale także polityczne i społeczne „,zmęczenie rozszerzaniem” wśród społeczeństw UE oraz związana z takim poszerzeniem konieczność reformy unijnych instytucji. Już teraz wspólne funkcjonowanie 27 państw członkowskich wymaga gruntownej reformy instytucjonalnej ${ }^{15}$.

Dla polskiej prezydencji dużym problemem stały się bułgarskie i rumuńskie starania o wejście do strefy Schengen, których przeciwnikami są Francuzi i Niemcy obawiający się masowej imigracji Romów ${ }^{16}$.

Przechodząc do omówienia wyznaczników strategicznych polskiej prezydencji należy podkreślić, że trzy z nich odgrywają kluczową rolę i znajdują się w orbicie szeroko rozumianych problemów bezpieczeństwa i współpracy międzynarodowej. Są to: 1) stosunki z Federacją Rosyjską; 2) Partnerstwo Wschodnie; 3) bezpieczeństwo europejskie, w tym bezpieczeństwo energetyczne i wzmacnianie unijnej polityki bezpieczeństwa i obrony.

\section{Stosunki z Federacją Rosyjską}

Jak dotąd Unia Europejska nie posiada żadnej rzeczywistej strategii wobec Federacji Rosyjskiej, w odróżnieniu od pozostałych wschodnich sąsiadów, którym zaproponowano koncepcję Partnerstwa Wschodniego. $Z$ tego względu w ramach unijnej polityki wobec Rosji, Polska zamierzała osiągnąć bardzo ambitny cel. Planowano

15 M. Klimowicz, Wyzwania Prezydencji Polski w Radzie Unii Europejskiej wobec wzmocnienia wspótpracy w ramach Europejskiego Obszaru Gospodarczego, w: 2011 Polska Prezydencja w Unii Europejskiej..., op. cit., s. 222.

16 J. Pawlicki, Unia po polsku..., op. cit. 
stworzenie długofalowej strategii wobec Federacji Rosyjskiej, która ma za zadanie powstrzymać niektóre państwa unijne przed próbą budowy stosunków z Rosją na zasadach bilateralnych, co często dzieje się wbrew interesom innych członków Unii. Ponadto, przedstawiciele Polski zabiegają o wprowadzenie ruchu bezwizowego między Rosją a UE. Planowane było również wprowadzenie małego ruchu granicznego między rosyjskim obwodem kaliningradzkim i północno-wschodnią Polską ${ }^{17}$. Kwestia współpracy z Rosją pojawiała się wśród wielu celów prezydencji Polski takich jak: Partnerstwo Wschodnie, współpraca w regionie Morza Bałtyckiego czy polityka energetyczna. $Z$ podobnych powodów bardzo istotne są i będą dobre relacje Unii Europejskiej z tym państwem, a także stosunki dwustronne. Zadaniem Polski stało się zbudowanie koalicji państw na rzecz opracowania strategii stosunków Unii Europejskiej z Rosją wokół takich obszarów jak: współpraca gospodarcza i energetyczna oraz w sferze bezpieczeństwa. Było to od początku obliczone na dłuższy okres niż czas trwania prezydencji i będzie raczej zadaniem niełatwym. Istnieje bowiem wiele obszarów potencjalnych konfliktów, do których zaliczyć należy m.in. często sprzeczne interesy w polityce zagranicznej UE i Rosji. W tym koncepcja Partnerstwa Wschodniego odbierana jest przez rosyjskie władze jako naruszenie rosyjskich interesów w ich strefie wpływów. Problemem jest także odmienne postrzeganie przyszłości systemu bezpieczeństwa w Europie, ale także nieprzystawalność kultur politycznych i systemów wartości. Spośród innych państw poradzieckich, ważnym wydaje się zbliżenie UE z Mołdawią oraz państwami kaukaskimi i wynegocjowanie dla nich umów stowarzyszeniowych ${ }^{18}$.

\section{Partnerstwo Wschodnie}

Wśród strategicznych priorytetów polskiej prezydencji poczesne miejsce zajmowała koncepcja Partnerstwa Wschodniego i promowanie polityki wschodniej. Zawierało się $\mathrm{w}$ tym forsowanie wspomnianych umów stowarzyszeniowych, tworzenie stref wolnego handlu, liberalizacja wizowa i handlowa oraz zintensyfikowana współpraca gospodarcza. Wpisuje się to w szerszy kontekst unijnej koncepcji budowania bezpieczeństwa międzynarodowego i związanego z tym - wpisanego do Europejskiej Strategii Bezpieczeństwa - przeciwdziałania zagrożeniom asymetrycznym.

Przyczyną oraz skutkiem dysproporcji ekonomiczno-społecznych są także takie zjawiska, jak: uchodźstwo, wojny i konflikty zbrojne, problem głodu czy ubóstwa, jak i występujące co jakiś czas kryzysy finansowe. Ponadto przestępczość zorganizowana, handel narkotykami i bronią czy terroryzm międzynarodowy. Tak pojmowane zjawiska asymetryczności czy dezintegracji są przeciwieństwem procesów integracyjnych i rozwojowych. Obie te tendencje mają charakter uniwersalny i w sposób bardzo znaczący wpływają na wydarzenia zachodzące na świecie. To, co występuje między opisywanymi płaszczyznami wywiera wpływ zarówno na zjawiska integracji czy symetrii oraz

17 Szerzej: A. Dudek, Szansa polskiej Prezydencji - wktad w polityke wschodnia Unii Europejskiej. Stosunki Rosja-UE, w: 2011 Polska Prezydencja w Unii Europejskiej ..., op. cit., s. 389-409.

18 Szerzej: ibidem, s. 389-409. 
dezintegracyjności i asymetrii, a tym samym na całokształt procesów politycznych, ekonomiczno-społecznych czy kulturowych funkcjonujących w świecie i wymaga podejmowania działań stymulujących ${ }^{19}$.

Jako że promowanie na obszarze poradzieckim stabilności, demokracji i wolnego rynku oraz stymulowanie rozwoju gospodarczego ma dla Unii Europejskiej znaczenie strategiczne w jej interesie jest zacieśnianie stosunków ze wschodnimi partnerami. Temu właśnie celowi służy m.in. propozycja Partnerstwa Wschodniego, zaaprobowana przez przywódców 27 państw 20 czerwca 2008 roku na szczycie w Brukseli, przyjęta przez Komisję Europejską 3 grudnia 2008 roku i zaakceptowana przez czeską prezydencję i państwa członkowskie na posiedzeniu Rady Europejskiej w Brukseli 19-20 marca 2009 roku. Jest to polsko-szwedzka idea wzmocnienia wymiaru wschodniego Europejskiej Polityki Sąsiedztwa, a zarazem najpoważniejszy sukces polskiej dyplomacji od momentu akcesji w UE. Celem inicjatywy jest stworzenie forum regionalnej współpracy 27 państw członkowskich UE z jej sześcioma sąsiadami wschodnimi: Ukraina, Mołdawią, Gruzją, Azerbejdżanem i Armenią oraz w ograniczonym zakresie z Białorusią ${ }^{20}$.

Jednym z najważniejszych zadań dla Partnerstwa Wschodniego jest wzmocnienie procesów demokratyzacji życia politycznego i gospodarczego w państwach Europy Wschodniej, których rozwój ma doprowadzić do wzrostu bezpieczeństwa i stabilizacji w regionie. Realizacja tego projektu ma doprowadzić, z jednej strony, do utrwalenia demokracji opartej na wspólnych europejskich wartościach, z drugiej zaś - wspomóc restrukturyzację gospodarek tych państw i pogłębić współpracę gospodarczą przez realizację konkretnych projektów. Inicjatywa ta przewiduje takie przedsięwzięcia jak: współpracę realizowaną na płaszczyźnie politycznej i bezpieczeństwa (współdziałanie w polityce zagranicznej i bezpieczeństwa, służb cywilnych i administracji samorządowej); uelastycznienie przepisów wizowych; usuwanie barier handlowych (strefa wolnego handlu); rozwój sieci transportowych i teleinformatycznych oraz energetyki (poprawa bezpieczeństwa energetycznego, poprawienia systemu wczesnego ostrzegania i gotowości na wypadek kryzysu, wsparcie procesu dywersyfikacji unijnych źródeł dostaw oraz tranzytu energii); współpraca przygraniczna i transgraniczna; kontakty międzyludzkie, rozwój współpracy między organizacjami pozarządowymi; czy programy edukacyjne i wspólne badania naukowe ${ }^{21}$.

Pod koniec polskiej prezydencji planowane jest spotkanie Forum Społeczeństwa Obywatelskiego w ramach Partnerstwa Wschodniego. To inicjatywa mająca ożywić organizacje pozarządowe z dawnych państw ZSRR oraz ułatwić im komunikację z władzami, a władze przekonać, by były bardziej otwarte na głos środowisk niezależnych. Polska chce także wzmacniać PW, poprzez pozyskiwanie dla niego poparcia

19 S. Wojciechowski, Asymetryczność ekonomiczno-społeczna wspótczesnego świata, w: Zagrożenia asymetryczne współczesnego świata, red. S. Wojciechowski, R. Fiedler, Poznań 2009, s. 56 .

${ }^{20}$ B. Piskorska, Partnerstwo Wschodnie. „Okręt flagowy" Unii Europejskiej i Polski w nadchodzacej Prezydencji, w: 2011 Polska Prezydencja w Unii Europejskiej..., op. cit., s. 371.

${ }^{21}$ L. Koćwin, Partnerstwo Wschodnie. Aktorzy i interesy regionalnej geopolityki Unii Europejskiej, w: 2011 Polska Prezydencja w Unii Europejskiej..., op. cit., s. 357-358. 
zainteresowanych nim państw spoza UE jak np.: Stany Zjednoczone, Japonia, Norwegia czy Kanada ${ }^{22}$.

\section{Bezpieczeństwo i bezpieczeństwo energetyczne}

Kolejnym ważnym zadaniem stało się wzmocnienie polityki energetycznej i zagadnienia związane $\mathrm{z}$ bezpieczeństwem energetycznym Unii Europejskiej. Polska proponuje w tym zakresie pogłębioną dyskusję na temat nowych rozwiązań, które pozwolą zachować konkurencyjność europejskiego sektora energetycznego i zamierza wypracować, w oparciu o nowe zapisy Traktatu lizbońskiego, mechanizmy prowadzenia solidarnej i konkurencyjnej polityki energetycznej.

W ramach Unii Europejskiej istnieje wiele podejść do kwestii bezpieczeństwa energetycznego, które można sprowadzić do jednej definicji. Stwierdza się w niej, iż „,bezpieczeństwo energetyczne to $\mathrm{w}$ uproszczeniu zdolność do niezawodnych dostaw energii i paliw po odpowiednich (akceptowalnych) cenach. W szerszym ujęciu można je określić także jako pokrycie zapotrzebowania odbiorców na paliwa i energię w sposób zapewniający jednocześnie: bezpieczeństwo technologiczne (praca urządzeń i instalacji); opłacalność inwestycji z punktu widzenia dostawców kapitału; ciagłość i niezawodność dostaw o odpowiednich standardach; oraz akceptowalną wysokość cen. Przy czym za akceptowalny poziom cen dla odbiorców indywidualnych należy uznać taki, który nie stanowi nadmiernego obciążenia budżetów domowych, zaś w odniesieniu do odbiorców przemysłowych taki, który nie powoduje nieopłacalności produkcji”. Przez bezpieczeństwo dostaw paliw i energii rozumie się zapewnienie stabilnych ich dostaw na poziomie gwarantującym zaspokojenie potrzeb krajowych i po akceptowanych przez gospodarkę i społeczeństwo cenach, przy założeniu optymalnego wykorzystania krajowych zasobów surowców energetycznych oraz przez dywersyfikacje źródeł i kierunków dostaw ropy naftowej, paliw ciekłych i gazowych. Dla Unii Europejskiej oznacza to zapewnienie zaopatrzenia w energię dla gospodarek poszczególnych państw członkowskich. Związane z tym aspekty, jak ochrona środowiska naturalnego, oszczędne korzystanie z energii, alternatywne i odnawialne źródła energii mogą być realizowane dopiero, gdy zapewnione zostanie, jako fundament, bezpieczeństwo dostaw energii. W tym kontekście można wyróżnić trzy główne, równorzędne i zazębiające się wzajemnie cele europejskiej polityki energetycznej: bezpieczeństwo energetyczne, konkurencyjny rynek energii; ograniczenie negatywnego wpływu sektora energii na środowisko (wzrost produkcji energii ze źródeł odnawialnych, poprawę efektywności energetycznej, ograniczenie emisji gazów cieplarnianych).

Przeszkodę na drodze tworzenia europejskiego bezpieczeństwa energetycznego stanowi pogłębiająca się zależność od importu surowców energetycznych. Wiąże się to z ryzykiem ekonomicznym i politycznym: w znacznej mierze dostawcy surowców energetycznych, zwłaszcza ropy i gazu, to państwa niestabilne politycznie lub leżące

22 M. Wojciechowski, Przybliżymy Unii Rosję. Przed polska prezydencja w UE, ,Gazeta Wyborcza”, 14.10.2010. Szerzej: L. Koćwin, Partnerstwo Wschodnie. Aktorzy i interesy regionalnej geopolityki Unii Europejskiej, w: 2011 Polska Prezydencja w Unii Europejskiej ..., op. cit., s. 357-371. 
w zapalnych regionach świata. Tymczasem polityka energetyczna Unii Europejskiej to bardzo dynamiczne zjawisko i otwartą pozostaje kwestia stopnia zaawansowania bezpieczeństwa energetycznego. Ważne jest też śledzenie sytuacji polityczno-gospodarczej w UE i na świecie, aby można było elastycznie reagować na bieżące układy w sferze energetyki. Jeszcze bardziej istotne wydaje się zbudowanie wzajemnych unijnych powiązań i zobowiązań w tym zakresie $^{23}$.

W kwestii bezpieczeństwa europejskiego, w czasie polskiej prezydencji celem jest prowadzenie debaty wokół tych czterech kluczowych aspektów, które wpłyną na kształt CSDP (ang. Common Security and Defence Policy, Wspólna Polityka Bezpieczeństwa i Obrony UE). Celem jest zwrócenie uwagi instytucji UE i jej państw członkowskich na potrzebę wypracowania usystematyzowanego stanowiska w tej sprawie. Podczas wystapienia inaugurującego kursu Wysokiego Szczebla Europejskiego Kolegium Bezpieczeństwa i Obrony (ang. European Security and Defence College - ESDC) szef polskiego MON Bogdan Klich na pierwszym miejscu wymienił rozwój zdolności wojskowych unijnych grup bojowych. Polska będzie namawiać inne kraje członkowskie, aby grupy bojowe mogły być używane jako tzw. Initial Entry Force (siły szybkiego reagowania, które wchodzą na teren ogarnięty kryzysem, kiedy jest potrzeba - oraz jako rezerwa operacyjna). Ponadto wśród priorytetów polskiej prezydencji minister Klich uwzględnił wzmocnienie militarnych zdolności UE, reformę struktury dowodzenia, podkreślając zwłaszcza rolę poprawy zdolności planowania i prowadzenia działań na poziomie strategicznym, a także harmonizację współpracy cywilno-wojskowej. W kontekście stosunków UE i NATO B. Klich zapowiedział, że celem polskiej prezydencji będzie wzmocnienie praktycznego wymiaru współpracy pomiędzy państwami członkowskimi obu organizacji. „UE w najbliższym czasie będzie musiała podjąć decyzje odnośnie do jakiejś formy działań, które będą się odnosić do tego, co się dzieje w północnej Afryce" - przyznał minister, i dodał, że Unia Europejska musi się liczyć m.in. ze zwiększonym napływem uciekinierów ${ }^{24}$.

W marcu 2011 roku polskie Ministerstwo Obrony Narodowej przedstawiło inne kluczowe priorytety polskiej prezydencji. Podczas inauguracji kursu Wysokiego Szczebla Europejskiego Kolegium Bezpieczeństwa i Obrony (ang. European Security and Defence College - ESDC), który miał miejsce w Akademii Obrony Narodowej, minister Bogdan Klich do najważniejszych zadań zaliczył: ,prowadzenie debaty wokół 4 kluczowych aspektów, które wpłyną na kształt CSDP (ang. Common Security and Defence Policy - Wspólna Polityka Bezpieczeństwa i Obrony UE), tak aby zachęcić instytucje UE, a przede wszystkim jej państwa członkowskie do wypracowania klarownego stanowiska w danej sprawie"25.

Na pierwszy plan wysuwa się wypracowanie roli i przeznaczenia unijnych grup bojowych, które w ocenie ministra jako ,coś, co nie jest używane, i coś, co nie ma jasno

${ }^{23}$ K. Załucki, Polityka energetyczna i bezpieczeństwo energetyczne Unii Europejskiej jako jeden z priorytetów polskiej Prezydencji, w: 2011 Polska Prezydencja w Unii Europejskiej, op. cit., s. $409-431$.

${ }^{24}$ Klich: cztery priorytety polskiej prezydencji $w$ dziedzinie bezpieczeństwa, http://www.euractiv.pl/polityka-zagraniczna/artykul/klich-cztery-priorytety-polskiej-prezydencji-w-dziedzinie-bezpieczestwa-002476 (08.03.2011).

25 Ibidem. 
określonego celu użycia, tak naprawdę jest rozwiązaniem papierowym [...] W związku z tym, będziemy namawiać inne kraje członkowskie, aby grupy bojowe mogły być używane jako tzw. Initial Entry Force - czyli takie siły szybkiego reagowania, które wchodzą na teren ogarnięty kryzysem, kiedy jest potrzeba - oraz jako rezerwa operacyjna”. Drugim polskim priorytetem ma być „wzmocnienie zdolności UE - co wiąże się z nowoczesnymi rodzajami sprzętu i uzbrojenia wojskowego - ponieważ prace nad tym toczą się i w UE, i w NATO, jest rzeczą oczywistą, że NATO z UE powinno harmonizować swoje prace w tym zakresie [...] NATO, i UE mają po kilkanaście obszarów, na których się koncentrują, a niektóre z nich są wspólne dla obu organizacji i ważne także dla Polski”.

Kolejnym priorytetem polskiej prezydencji w obszarze bezpieczeństwa jest poprawa relacji między Unią Europejską i Sojuszem Północnoatlantyckim. W tym kontekście szef polskiego ministerstwa obrony podkreślił, że współpraca między obu organizacjami jest obecnie lepsza niż kilka lat temu, ale w dalszym ciagu nie jest satysfakcjonująca. Minister Klich uznał: ,[...] że powinna zostać wzmocniona podstawa prawna dla współpracy obu organizacji, dlatego że ta, która w tej chwili istnieje, nie przewiduje współpracy między UE a NATO na teatrach, gdzie obie organizacje prowadzą swoje działania wojskowe. [...] takie miejsca jak Kosowo czy Afganistan”. Dodał, że organizacje powinny zsynchronizować posunięcia w zakresie pracy nad uzbrojeniem, by „nie wydawać dwukrotnie pieniędzy na to samo". Czwartym priorytetem polskiej prezydencji w kwestiach bezpieczeństwa ma być pojawiająca się już wcześniej współpraca z partnerami na wschodzie. Szef MON wymienił w tym kontekście „dopuszczenie i wzmocnienie udziału" naszych wschodnich sąsiadów w operacjach prowadzonych przez UE. Jak tłumaczył szef MON, obecnie tylko Ukraina ma podpisane porozumienie z UE o udziale w operacjach unijnych, natomiast Polska chce, by także inne państwa Partnerstwa Wschodniego miały zagwarantowaną możliwość uczestniczenia w misjach i operacjach $\mathrm{UE}^{26}$.

Niezwykle istotnym czynnikiem współgrającym z prezydencją, stała się ogólna sytuacja na arenie międzynarodowej, gdyż podejmowane decyzje nie są autonomiczne i muszą znaleźć aprobatę pozostałych państw członkowskich.

Z pewnością palącym problemem pozostaje sytuacja w Afryce Północnej, a Polsce przypadło w tym przypadku skomplikowane zadanie balansowania pomiędzy aspiracjami Francji, Włoch czy Wielkiej Brytanii, które mają w tym regionie specjalne interesy. Uznać należy, iż odmowa udziału w operacji militarnej w Libii osłabiła pozycję negocjacyjną Polski. Zwłaszcza, że waga głosu w europejskiej debacie dotyczącej unijnego bezpieczeństwa jest mierzona siłą praktycznego zaangażowania w problemy z tym związane i zdolnościami państw członkowskich w tej materii. Dążąc do odgrywania roli istotnego gracza w Unii Europejskiej, władze Polski powinny podejmować decyzje na miarę takiej pozycji. Zwłaszcza, że w przypadku Libii główny ciężar argumentów na rzecz działań militarnych leżał po stronie takich wartości jak chociażby obrona praw człowieka. Polska nie podważyła celów interwencji, ale reprezentanci RP

${ }^{26}$ MON: cztery priorytety prezydencji w dziedzinie bezpieczeństwa, „Gazeta Wyborcza”, 7.03.2011. 
tłumaczyli się brakiem środków, co źle świadczyło o podejściu przyszłego animatora prezydencji do idei solidarności europejskiej.

$* * *$

Ten ogólny zarys nie obejmuje wszystkich problemów gnębiących Unię Europejską, z którymi musi zmierzyć się polska prezydencja. Jednak najważniejsze jest takie sprawowanie przewodnictwa, aby uzyskać wizerunek odpowiedzialnego członka Unii Europejskiej, realizującego w pierwszym rzędzie interesy wspólnotowe (istota prezydencji) i umiejącego w nie wpleść i zrealizować interesy narodowe. Sprawując prezydencję Polska stała się koordynatorem setek spotkań i zmierzyła się z bieżącą polityką Unii Europejskiej w skali wcześniej nieporównywalnej. Nawet przy okrojonych prerogatywach prezydencji było to ogromne zadanie logistyczne.

W czasie kiedy powstaje niniejszy tekst, czyli jeszcze przed zakończeniem polskiej prezydencji, trudno jest przesądzać jak zapisze się ona w annałach unijnych. Promocja prezydencji w mediach sprawiła, iż opinia publiczna w kraju zyskała przesadne wyobrażenie o jej roli w Unii Europejskiej. Tymczasem strategiczne polskie priorytety wyżej wymienione, mogły być dzięki sprawowaniu prezydencji jedynie wplecione w system sprawnej organizacji posiedzeń przedstawicieli rządów państw członkowskich, moderowania dyskusji i szukania kompromisów. Prezydencja, jako taka musiała być sprawowana bezstronnie, bez forsowania interesów narodowych. Na efekty jej sprawowania przyjdzie zapewne poczekać, gdyż jeśli udało się zainicjować dyskusje w wybranych obszarach, będąc przez pół roku współorganizatorem życia politycznego Unii Europejskiej, to znając realia unijne wymaga to wiele czasu i negocjacji w dłuższej perspektywie.

Na realizację priorytetów polskiej prezydencji rzutowały niewątpliwie bieżące wydarzenia, w tym zwłaszcza kryzys finansów publicznych. Zadaniem prezydencji stała się sprawa dokończenia reform w strefie euro, czyli przyjęcia tzw. sześciu ustaw (sześciopaku). 12 września 2011 roku ministrowie finansów państw członkowskich UE osiagnęli we Wrocławiu porozumienie w sprawie sześciu aktów prawnych, które wzmocniły koordynację polityk gospodarczych w UE i wzmocniły dyscyplinę finansów publicznych. Głównymi założeniami przyjętych ustaw jest kontrolowanie długów państw, wprowadzenie kar finansowych dla państw, które nie przestrzegają zasad polityki budżetowej, a także wzmocnienie rządów do przestrzegania wspólnych uzgodnień. Efekty spotkania ministrów finansów państw UE pozwoliły polskiej prezydencji zakończyć niezbędne formalne procedury, to z kolei umożliwiło przegłosowanie przez Parlament Europejski pakietu sześciu aktów prawnych jeszcze we wrześniu 2011 roku. Przyspieszyło to wejście w życie przepisów dotyczących zarządzania gospodarczego w $\mathrm{UE}^{27}$. Doprowadzenie do kompromisu przez polską prezydencję było wielkim sukcesem i podniosło prestiż Polski na arenie politycznej.

Tego typu przykładów jest wiele. Rozpoczęte w czasie polskiego przewodnictwa prace nad projektem unijnego rozporządzenia dotyczącego ułatwień w e-handlu mają

27 Tzw. sześciopak reform finansowych UE uzgodniony, „Gazeta Wyborcza”, 16.09.2011. 
szansę zakończyć po roku debat. Pogłębienie jednolitego rynku wewnętrznego, w celu pełnego wykorzystania jego potencjału, było jednym z priorytetów polskiej prezydencji i w związku z tym opracowano projekt unijnego rozporządzenia w sprawie europejskiego prawa umów, które ma znieść bariery uniemożliwiające przeprowadzanie transakcji transgranicznych on-line ${ }^{28}$. Innym przykładem jest wspólny list Radosława Sikorskiego i Guido Westerwellego skierowany do szefowej unijnej dyplomacji Catherine Ashton i pozostałych państw członkowskich, w którym podkreśla się, że Unia Europejska pomoże Rosji w modernizacji, ale w zamian za wdrażanie demokratyzacji oraz obietnicę pozostania przewidywalnym partnerem w polityce międzynarodowej i energetycznej ${ }^{29}$. W ramach przewodnictwa Polski w Radzie UE doszło w Poznaniu w listopadzie 2011 roku do spotkania ministrów zdrowia państw UE. Zainicjowano dyskusję o likwidacji nierówności w zakresie zdrowia mieszkańców poszczególnych państw członkowskich ${ }^{30}$.

W ramach prezydencji Ministerstwo Gospodarki zorganizowało konferencję „Boosting trust in the digital single market: the role of e-signature", $\mathrm{z}$ udziałem przedstawicieli Komisji Europejskiej oraz państw członkowskich UE. Służyła ona wypracowaniu rozwiązań, które mają znowelizować dyrektywę 1999/93/WE w sprawie wspólnotowych ram w zakresie podpisów elektronicznych, która nie wystarcza już do uregulowania obecnej sytuacji rynkowej. Polsce zależało na ustanowieniu wspólnych standardów w tej dziedzinie. Obecnie prawo państw członkowskich znacznie się różni, jeśli chodzi o zasady uzyskiwania i uznawania podpisów ${ }^{31}$.

Jednym z najważniejszych wydarzeń polskiej prezydencji w Radzie Unii Europejskiej był odbywający się w dniach 29-30 września 2011 roku Szczyt Partnerstwa Wschodniego. To dwudniowe spotkanie szefów państw i rządów podjęło strategiczne decyzje w sprawie kształtu Partnerstwa Wschodniego w kolejnych latach. Szczyt dał polityczny sygnał w sprawie dalszego pogłębiania integracji europejskiej wschodnich sąsiadów UE, a zarazem jego uczestnicy podsumowali dotychczasowe osiagnięcia partnerstwa, przyczyniające się do zbliżania państw partnerskich do norm, standardów i wartości europejskich oraz ułatwiających im polityczne stowarzyszenie i integrację gospodarczą z UE. Spotkanie zakończyło się przyjęciem wspólnej deklaracji, która dała czytelny sygnał wszystkim sześciu państwom partnerstwa, że Unia Europejska jest gotowa im pomagać, rozmawiać o ich europejskich aspiracjach i o formach ściślejszej

${ }^{28}$ Kompleksowy zestaw obowiązków i uprawnień, na zasadzie których w UE dokonywano by sprzedaży przez internet. Ma zaowocować umieszczeniem na stronach internetowych sprzedawców „niebieskiego guzika”, którego kliknięcie oznaczałoby, że transakcja odbywa się na zasadach określonych w europejskim rozporządzeniu, a nie według prawa krajowego. Polską inicjatywę określa się mianem ,prawa niebieskiego guzika”. Szerzej: Kwiatkowski: europejskie prawo dot. e-handlu-może już za rok, „Gazeta Prawna”, 10.11.2011.

${ }_{29}$ Szerzej: Znaczaca inicjatywa Polski i Niemiec ws. relacji UE-Rosja, „Gazeta Prawna”, 12.11.2011.

30 Efektem spotkania są rekomendacje do tzw. konkluzji w ramach najważniejszych priorytetów polskiej prezydencji. Są to wskazówki dla Komisji Europejskiej i wszystkich państw UE, w jaki sposób prowadzić politykę zdrowotną, by różnice w zdrowiu się zmniejszały.

${ }^{31}$ Polska pracuje nad ujednoliceniem przepisów dotyczacych podpisu elektronicznego, http://pl2011.eu/content/polska-pracuje-nad-ujednoliceniem-przepisow-dotyczacych-podpisu-elektronicznego (11.11.2011). 
integracji. Uczestnicy szczytu przyjęli wprawdzie deklarację końcową, ale nie odnieśli się w niej jednomyślnie do sytuacji na Białorusi. Pod osobną deklaracją dotyczącą Białorusi podpisali się tylko szefowie państw UE, zabrakło podpisów wschodnioeuropejskich państw włączonych do Partnerstwa Wschodniego. Pozornie można by sądzić, iż to niewiele, ale jest to jeden z najbardziej zaawansowanych i dofinasowanych programów w ramach Europejskiej Polityki Sąsiedztwa i jest obliczony na działanie długofalowe.

Przykłady osiagnięć polskiej prezydencji można mnożyć, ale na skutki wielu z tych działań trzeba poczekać. Nie ulega jednak wątpliwości, że wielu polskich urzędników i polityków zyskało dzięki sześciu miesiącom szczególnej aktywności niebagatelne doświadczenie w działaniu w unijnych strukturach.

Ciekawym przyczynkiem do analizy polskiej prezydencji wydaje się pozytywna ocena wystawiona podczas konferencji na temat roli Europy Środkowo-Wschodniej w stosunkach transatlantyckich, która odbyła się 14 października 2011 roku w Centrum Studiów Strategicznych i Międzynarodowych w Waszyngtonie. Ekspert waszyngtońskiego Centrum Analiz Polityki Europejskiej (CEPA) Robert Kron, podsumowując polskie przewodnictwo w Radzie UE stwierdził, że „cechują je «trzy C»: confidence (wiara w siebie), competence (kompetencje) i comfort within EU (dobra pozycja w Unii Europejskiej) [...] prezydencję ułatwia Polsce stosunkowo dobra sytuacja gospodarcza i stabilny rząd. Jest to prezydencja dobrze przygotowana, z właściwymi celami. Ambitna, ale nie ponad miare”". Za sukcesy polskiej prezydencji uznał „,postępy w kształtowaniu wspólnej polityki energetycznej Unii”. Jego zdaniem, UE jest dziś bliższa takiej polityce, niż podczas prezydencji węgierskiej. Ponadto „Polska dobrze promuje dywersyfikację źródeł energii, czego przykładem jest terminal LNG w Świnoujściu"32.

Pojawiają się również głosy sceptycznie oceniające polską aktywność w omawianym kontekście - głównie wśród niezależnych analityków, a także głosy jawnie krytyczne - najbardziej rzeczowe narodziły się w łonie opozycji parlamentarnej. Jednak podobnie jak sprawowanie prezydencji niewątpliwie przysłużyło się rządzącej koalicji podczas parlamentarnej kampanii wyborczej na przełomie lata i jesieni 2011 roku, tak i opozycji służyło do podobnych celów. O ile trudno odmówić polskiemu przewodnictwu w Radzie UE licznych sukcesów i sprawnej organizacji prac Rady - przy nieco nadmiernym eksponowaniu znaczenia tego problemu, o tyle argumenty wysuwane przez oponentów, przed upływem półrocznej polskiej kadencji w Radzie UE, w wielu przypadkach wydały się przedwczesne, często nieuzasadnione, czy wynikające w politycznej zaciekłości, a nierzadko były efektem zwykłej niewiedzy, co do istoty prezydencji albo jej mitologizowania ${ }^{33}$.

32 USA: pozytywna ocena polskiej prezydencji, RC/PAP, 14.10.2011, http://wiadomosci.onet.pl/ raporty/polskie-przewodnictwo-w-ue/usa-pozytywna-ocena-polskiej-prezydencji,1,4881378, wiadomosc.html (18.10.2011).

${ }_{33}$ Patrz szerzej: Eurodeputowany, były minister spraw zagranicznych, Dariusz Rosati podczas debaty zatytułowanej „Ocena pierwszych miesięcy polskiej prezydencji”, stwierdził m.in., że „Nie można na razie przesądzić, czy polska prezydencja UE zapisze się dobrze, czy źle w annałach unijnych” - według D. Rosatiego - „opinia publiczna w kraju ma przesadne wyobrażenie o roli prezydencji w UE. Tymczasem należy do niej sprawna organizacja posiedzeń przedstawicieli rządów krajów 
Niewatpliwie bezprecedensowy kryzys strefy euro zepchnął spektakl prezydencji na dalszy plan wydarzeń europejskich i przyćmił nieco polskie starania. Niemniej jednak pamiętać należy, iż przewodnictwo w Radzie UE polega de facto na organizowaniu jej prac. Państwo sprawujące prezydencję, na sześć miesięcy staje się gospodarzem większości unijnych wydarzeń i odgrywa kluczową rolę w działaniach Unii Europejskiej. Jego powinnością jest nadawanie kierunku politycznego Unii Europejskiej, dbanie o jej rozwój, integrację oraz bezpieczeństwo. Traktat lizboński znacząco zmienił konfigurację prezydencji, zwłaszcza w kontekście unijnych stosunków zewnętrznych. W konsekwencji powinno się mówić o nowym ukonstytuowaniu się prezydencji i kształtowaniu jej nowej pozycji w UE.

Trzeba przyznać, że w świetle kryzysu zewnętrznego, jakim była sytuacja w Afryce Północnej i na Bliskim Wschodzie w 2011 roku, doszło do delegitymizacji prezydencji w dziedzinie zarządzania jej stosunkami zewnętrznymi, na korzyść Wysokiego Przedstawiciela Unii Europejskiej ds. Wspólnej Polityki Zagranicznej i Bezpieczeństwa jako odpowiedzialnego za prowadzenie Wspólnej Polityki Zagranicznej i Bezpieczeństwa oraz Europejskiej Polityki Bezpieczeństwa i Obrony, a jeszcze bardziej arbitralnych działań państw mających szczególne interesy we wspomnianym regionie.

Jeśli chodzi o związany z rotacyjną prezydencją postulat zapewnienia spójności i kontynuacji w zarządzaniu Unią Europejska, to polskie przewodnictwo dało pozytywną odpowiedź na pojawiające się w tym zakresie wątpliwości. Natomiast w świetle działań związanych z kryzysem gospodarczym w Unii Europejskiej, a zwłaszcza w strefie euro, trudno mówić o zapewnieniu odpowiedniego miejsca w działaniach UE politykom państwa sprawującego rotacyjną prezydencję, o ile nie należy ono do gospodarczej unijnej elity. Pozostaje im rola koordynacyjna i wspierająca, ale nie pierwszoplanowa.

Zatem w nowej formule balansu instytucjonalnego w Unii Europejskiej rola prezydencji nadal będzie zależała od pozycji państwa w Unii Europejskiej i będzie oscylowała w szerokim przedziale od roli organizatora do roli lidera, w zależności od koniunktury i sytuacji międzynarodowej. Wypracowanie pozycji ustrojowej prezydencji po wejściu w życie Traktatu lizbońskiego wymaga zdecydowanie dłuższej praktyki

członkowskich, moderowanie dyskusji i szukanie kompromisów, gdy zajdzie taka potrzeba. Prezydencja musi przy tym zachować bezstronność i nie forsować interesów narodowych”. Patrz: P. Stefaniak, Plus za organizację dla polskiej prezydencji UE, minus - za brak inicjatyw, Portal ekonomiczny wnp.pl 30.08.2011, http://www.wnp.pl/informacje/plus-za-organizacje-dla-polskiej-prezydencji-ue-minus-za-brak-inicjatyw,149044_1_0_0.html (19.10.2011); Witold Waszczykowski - były wiceminister spraw zagranicznych i wiceszef BBN, w rozmowie z Jackiem Nizinkiewiczem [Ostra ocena polskiej prezydencji. Może jeszcze lot w kosmos?, http://wiadomosci.onet.pl/tylko-w-onecie/ostra-ocena-polskiej-prezydencji-moze-jeszcze-lot-,1,4784037,wiadomosc.html (20.10.2011], powiedział m.in.: „Priorytety prezydencji są tak ogólnie sformułowane, że trudno się do nich odnieść. Chcemy Europę bronić, rozwijać i rozszerzać. I to wszystko w trzy, cztery miesiące, jeśli odliczy się wakacje i okres przedświąteczny. Może jeszcze zadeklarujemy lot w kosmos? A co tam! Są to więc ogólniki, z których trudno będzie rozliczać prezydencję. Oczywiście, że nie jesteśmy państwem współdecydującym o polityce Unii. Ten rząd zmarginalizował naszą pozycję w Europie. Z kolei Stanisław Żerko w swoim artykule Polityczny teatr zamiast dyplomacji („Rzeczpospolita”, 30.09.2011) powołuje się na wywiad telewizyjny J. Delorsa, w którym z ubolewaniem przyznał on, że polska Prezydencja jest ignorowana, a Polska - pomijana. 
politycznej, ale wiele wskazuje na to, że nie uzyskamy w tej materii equilibrium. Co do polskiej prezydencji, to jej efekty, wyniki, sukcesy i porażki wymagają jeszcze pogłębionej analizy w oparciu o dane dotyczące całokształtu naszego przewodnictwa w Unii Europejskiej po zakończeniu działań z tym związanych, podjętej z nieco dłuższej perspektywy czasu.

\title{
STRESZCZENIE
}

Autor wskazuje wybrane obszary priorytetowe polskiej prezydencji w Unii Europejskiej. W szczególności analizie poddano przyszłość polityki rozszerzenia, Partnerstwa Wschodniego, polityki energetycznej Unii Europejskiej, a także kwestie polityki obrony, między innymi możliwości rozwoju zdolności militarnych, dyskusji nad ideą grup bojowych UE i ustanowienia wspólnego dowództwa, co wzmocni zdolności planowania i prowadzenia operacji.

\section{STRATEGIC CHALLENGES TO POLISH FOREIGN POLICY IN THE CONTEXT OF ITS PRESIDENCY IN THE COUNCIL OF EUROPEAN UNION IN 2011}

\begin{abstract}
The contribution refers to selected priority areas of the Polish Presidency in the EU. The topics include the future EU Financial Framework; future of the EU enlargement policy, Eastern Partnership; the EU Energy Policy and especially areas of defense policy during Presidency: development of military capabilities, with a focus on pooling and sharing and the revival of the discussion on the increase of usefulness and flexibility of EU Battle Groups and strengthening EU capabilities, reform of its command structure, in particular improvement of planning capabilities and conducting operations at strategic level.
\end{abstract}

